\title{
CHARACTERIZATION OF SEVERAL GENERATIONS OF NiMo HYDROPROCESSING CATALYSTS EMPLOYED IN THE SAME HYDROTREATER
}

Tatiana Marques Pessanhaa, Carolina Leão Quintanilhaa ${ }^{a}$, Cristiano Nunes da Silva ${ }^{\mathrm{a}}$ and Julio Carlos Afonso*,a,®

Departamento de Química Analítica, Instituto de Química, Universidade Federal do Rio de Janeiro, 21941-909 Ilha do Fundão - RJ, Brasil

Recebido em 13/10/2018; aceito em 17/01/2019; publicado na web em 27/02/2019

\begin{abstract}
This work details the chemical characterization of four $\mathrm{NiMo} / \mathrm{Al}_{2} \mathrm{O}_{3}$ hydroprocessing generation catalysts (1979-1986, 1993-1998, 2003-2008 and 2008-2011) employed to perform hydrodesulfurization (HDS) of diesel fractions in the same hydrotreater of a Brazilian refinery. The basic differences are the quality of the feedstocks and the HDS experimental conditions. Samples were characterized by X-ray fluorescence, X-ray diffraction, ${ }^{13} \mathrm{C}$ CP-MAS NMR, elemental analysis, loss of volatiles, specific surface area and average pore volume. The amount and variety of foreign elements deposited on the catalyst increased in the most recent generations due to the higher amounts of impurities in the processed feedstocks. Coke became more aromatic and loss of textural properties was more prominent in these samples as expected from the more drastic HDS conditions and the quality of the crude diesel. On the other hand, loss of volatiles was lower due to the low carbon content, partial oxidation of sulfur to sulfate species and oxidation of some elements deposited on the catalyst. Coke tended to ignite as it became more aromatic. For this reason, leaching of decoked samples from the most recent generations by sulfuric acid presented very low yields due to the formation of refractory oxides that are insoluble in the leachant.
\end{abstract}

Keywords: spent catalysts; coke; metals deposition; catalyst characterization; catalyst leaching.

\section{INTRODUCTION}

Over the years, refineries have been processing heavier and sourer feeds due to shifting crude diversity and sources. Maximizing of liquid products yield from various processes and valorization of residues are of immediate attention to refiners. ${ }^{1}$ Hydroprocessing is a key technology for the production of clean fuels in today's refineries operations because of the high concentrations of sulfur, nitrogen, and metals along with a high proportion of coke precursors in such feedstocks..$^{2-5}$ The petroleum refining industry needs a large amount of catalyst to purify and refine such crudes because a high conversion level is required. ${ }^{6}$ Hydroprocessing catalysts are mostly based on $\mathrm{Ni}$, Co, Mo and W sulfides. ${ }^{2,7}$ They account for about one-third of the total worldwide catalyst consumption..$^{8,9}$

At present environmental directories impose severe restrictions concerning gas and particle emissions from refineries and fuels..$^{9,10}$ Deep hydrodesulfurization (HDS) of diesel has become an important issue in recent years due to stringent regulations that require low sulfur levels $\left(<10 \mathrm{mg} \mathrm{kg}^{-1}\right)$ in this fuel. ${ }^{7,11,12}$ Those levels can only be reached by hardening the working conditions (increase of temperature, lower space velocity and higher hydrogen partial pressure), improving efficiency of the existing processes ${ }^{13}$ or using more active catalysts with good tolerance to deactivation. . $^{3,11,12,14}$

The heavier and more contaminated feedstock, the faster the catalyst deactivation, ${ }^{1,15}$ particularly when the crude oil has high percentage of asphaltenes, ${ }^{1,16}$ and at severe reaction conditions. ${ }^{4,9}$ This phenomenon will become more and more critical due to the ongoing trend in increasing hydroprocessing severity and maximizing catalyst performance to meet fuels quality. ${ }^{1,2,17}$ To maintain constant product yields and/or quality, the loss of catalytic activity must be compensated by periodic increases of reaction temperature. ${ }^{1,6,8}$

Catalyst deactivation plays an important role in process design and operation within the petrochemical and petroleum industry both from

*e-mail: julio@iq.ufrj.br an economic and technological point of view. ${ }^{1,2,15,18-20}$ Hydroprocessing catalysts are deactivated by coke, oil and elements deposition. ${ }^{19,21}$ They contain sulfur and can ignite spontaneously in air due to presence of the flammable oil and metal sulfides. This is an important factor that endangers the local environmental quality. ${ }^{6}$ The Environmental Protection Agency (EPA) has considered the spent hydroprocessing catalyst as a hazardous material. ${ }^{10,19}$

Coke deposition on the catalyst is generally believed to be the primary cause of catalyst deactivation. ${ }^{11,16,18,22,23}$ It is formed very rapidly at the early stages of hydroprocessing reactions. ${ }^{1}$ The pores of the catalyst are physically blocked, preventing the diffusing reactants from entering the pore structure. ${ }^{22,23}$ The rate of coke formation enhances with increasing reaction temperature. ${ }^{23}$ Oil deposition also reduce surface area and pore volume of catalysts with prolonged time of use. ${ }^{21}$

Sintering or segregation of the active phase,,$^{12,22-26}$ poisoning by nitrogen-containing compounds and elements deposition (silicon, calcium, iron, arsenic etc. $)^{11}$ also lead to loss of activity. Elements deposition takes place at longer period than coke. ${ }^{1}$ The presence of vanadium and nickel in crude feedstocks is of particular interest. These metals are usually distributed between porphyrin and non-porphyrin type structures. They are accumulated as metal sulfides in the pore mouth of the catalyst and block the way of the reactants to enter. ${ }^{23}$

The most common characterization techniques to monitor the changes in catalyst activity during commercial operation are textural properties (surface area, pore volume, average pore diameter and pore size distribution), ${ }^{1,4}$ elements ${ }^{8,10}$ and carbon content. ${ }^{1,21}$ Carbonaceous deposits have been characterized by solubility tests (solvent extraction) and several instrumental techniques. ${ }^{1,6,10,14,22,27}$ Solid-state ${ }^{13} \mathrm{C} \mathrm{NMR}$ has the unique ability to determine the distribution of aromatic, aliphatic and other carbon types present. ${ }^{14,18,22}$

It is an important issue to study the deactivation of hydroprocessing catalysts by investigating the state and distribution of deposited species (coke and elements) on the catalyst. ${ }^{9,15}$ The investigation of samples withdrawn from an industrial or pilot reactor provide valuable 
information to develop recovery processes of valuable metals $(\mathrm{Ni}, \mathrm{Co}$, Mo, W) from spent catalysts. ${ }^{1,2,6,22,24,28,29}$ In these studies, coke must be eliminated under an oxidizing atmosphere at high temperature $\left(450-550^{\circ} \mathrm{C}\right)$ and low heating rate prior to leaching in order to increase metals exposure to the leachant. ${ }^{7,24,28}$

This work presents a unique study on the deactivation of several generations of spent hydroprocessing catalysts (covering over 30 years) used in the same hydrotreater to perform hydrodesulfurization (HDS) of crude diesel fractions. Their chemical composition and the nature of coke and elements deposited on the catalyst surfaces were determined to understand the behavior of samples subjected to leaching with sulfuric acid after coke removal.

\section{EXPERIMENTAL}

\section{Spent catalysts}

Four generations of spent $\mathrm{NiMo} / \mathrm{Al}_{2} \mathrm{O}_{3}$ catalysts $(5 \mathrm{~mm}$ cylinder extruded, $1.2 \mathrm{~mm}$ diameter) covering a 32 year period (1979-1986, 1993-1998, 2003-2008 and 2008-2011) were employed. These catalysts worked in the sulfided form in the same hydrotreater of a Brazilian refinery. This unit is designed for HDS of crude diesel fractions obtained after processing various crude oils. Table 1 presents some data of the feedstocks processed, the crude diesel fractions and the HDS experimental conditions.

Data of Table 1 indicate that the quality of the feedstock became progressively heavier as shown by the higher density and amounts of $\mathrm{Ni}, \mathrm{V}, \mathrm{S}$ and $\mathrm{N}$ (there is no significant difference between the feedstocks treated by the third and fourth NiMo generation catalysts). The quality of the crude diesel follows the same trend. The first and second NiMo generation catalysts worked under classical HDS conditions, the third generation worked as such from 2003 to 2007, but ultra-deep HDS was introduced in 2008. The last generation worked only under ultra-deep HDS conditions. ${ }^{12,26,30-33}$
The hydrotreater design remained the same along the period 19792011. Only routine maintenance was performed (change of corroded components, removal of accumulated solids etc.). The use of current commercial HDS catalysts without changing the reactor volume means that the catalyst activity must have increased to meet the new diesel regulation. ${ }^{33}$ This can be achieved with high metal loading, minimal support-metal interaction or additional catalyst volume..$^{32,33}$

The bed temperature was gradually increased during the reactor run to compensate for the effects of catalyst deactivation and in order to produce consistent product quality in the face of varying catalyst activity and feed quality. . $^{1,6,6,9,16,21-26,33} \mathrm{H}_{2}$ pressure was also gradually increased from the first to the last NiMo generation catalyst. ${ }^{21,22,24}$ This also reflects the more severe conditions required to ultra-deep HDS. Finally, the liquid hourly space velocity (LHSV) decreased along the NiMo generation catalysts. The decrease of LHSV increases the diesel-catalyst contact time. More refractory sulfur compounds require lower space velocity for achieving deeper HDS. ${ }^{21,22}$

When the catalyst was taken out of the hydrotreater, the residual oil and other impurities adhered to the catalyst surface were removed by Soxhlet extraction in oxygen-free toluene for $\sim 12 \mathrm{~h}$. The spent catalysts were subsequently dried at $110^{\circ} \mathrm{C}$ for $2 \mathrm{~h}$ in dried $\mathrm{N}_{2}$ flow. ${ }^{13-15}$ Samples were not ground. They were stored under nitrogen in the dark at room temperature.

\section{Oxidation of samples (loss of volatiles)}

Samples were placed in identical ceramic crucibles. Since they were not ground, catalyst height in the crucible was fixed at $5 \mathrm{~mm}$. Oxidation was performed in a furnace at $500^{\circ} \mathrm{C}\left(3^{\circ} \mathrm{C} \mathrm{min}-1\right)$ for $5 \mathrm{~h}$, according to previous studies in our laboratory. ${ }^{7}$ Temperature of the catalytic bed was monitored by a thermocouple placed on its surface. The roasted mass was cooled down in the furnace and transferred to a desiccator. The experiments were run in triplicate, and errors for each experiment were always below $3 \%$.

Table 1. Feedstocks, crude diesel and HDS data

\begin{tabular}{|c|c|c|c|c|}
\hline NiMo generation catalyst & I & II & III & IV \\
\hline Time on stream (years) & $7(1979-1986)$ & $5(1993-1998)$ & $5(2003-2008)$ & $3(2008-2011)$ \\
\hline \multicolumn{5}{|c|}{ Feedstocks } \\
\hline Type & Arabian light & $\begin{array}{c}\text { Arabian light (principal) }+ \\
\text { Campos Basin }\end{array}$ & $\begin{array}{c}\text { Arabian light }+ \text { Campos Basin } \\
\text { (principal) }\end{array}$ & $\begin{array}{c}\text { Arabian light }+ \text { Campos Basin } \\
\text { (principal) }\end{array}$ \\
\hline Density $\left(\mathrm{kg} \mathrm{m}^{-3}\right)$ & 0.86 & 0.88 & 0.90 & 0.92 \\
\hline S content (wt.\%) & 1.5 & 1.3 & 1.1 & 1.2 \\
\hline $\mathrm{N}$ content (wt.\%) & 0.1 & 0.3 & 0.4 & 0.5 \\
\hline $\mathrm{Ni}\left(\mathrm{mg} \mathrm{kg}^{-1}\right)$ & 3 & 8 & 15 & 20 \\
\hline $\mathrm{V}\left(\mathrm{mg} \mathrm{kg}^{-1}\right)$ & 8 & 12 & 20 & 25 \\
\hline \multicolumn{5}{|c|}{ Crude diesel } \\
\hline Density $\left(\mathrm{kg} \mathrm{m}^{-3}\right)$ & 0.84 & 0.87 & 0.88 & 0.89 \\
\hline S content (wt.\%) & 0.2 & 0.3 & 0.5 & 0.5 \\
\hline $\mathrm{N}$ content (wt.\%) & 0.3 & 0.5 & 0.5 & 0.6 \\
\hline $\mathrm{Ni}\left(\mathrm{mg} \mathrm{kg}^{-1}\right)$ & $<0.1$ & 0.1 & 1 & 1 \\
\hline $\mathrm{V}\left(\mathrm{mg} \mathrm{kg}^{-1}\right)$ & $<0.1$ & 0.1 & 2 & 3 \\
\hline Boiling range $\left({ }^{\circ} \mathrm{C}\right)$ & $170-340$ & $170-350$ & $170-380$ & $170-380$ \\
\hline \multicolumn{5}{|c|}{ HDS conditions } \\
\hline WHSV $\left(h^{-1}\right)$ & $1.5-2.0$ & $1.5-2.0$ & $1.0-1.5$ & $1.0-1.5$ \\
\hline $\mathrm{P}(\mathrm{MPa})$ & $2-5$ & $3-6$ & $3-8$ & $4-10$ \\
\hline $\mathrm{T}\left({ }^{\circ} \mathrm{C}\right)$ & $320-350$ & $320-380$ & $320-400$ & $350-410$ \\
\hline
\end{tabular}




\section{Leaching of oxidized samples}

Sulfuric acid was used as leachant. According to literature studies, this acid is by far the most common leachant for processing spent catalysts. $^{7,21,33}$ The experimental procedure is described in detail in the literature. ${ }^{7}$ The experiments were run in triplicate, and errors for each experiment were always below $5 \%$.

\section{Analytical methods}

Solid-state CP-MAS ${ }^{13} \mathrm{C}$ NMR was used to determine the carbon types present in the coke. Samples were crushed using a pestle and mortar so as to produce a fine powder, and then packed into a sample rotor to which a serrated cap was fitted. All experiments were performed on an AVANCE III/400 NMR spectrometer equipped with a $4 \mathrm{~mm}$ broadband CP/MAS probe using a magic angle spinning rate of $8 \mathrm{kHz}$. The instrument was tuned to a resonant ${ }^{1} \mathrm{H}$ frequency of 400.25 MHz and a ${ }^{13} \mathrm{C}$ frequency of 100.64 MHz. Hexamethylbenzene $\left(\mathrm{CH}_{3}\right.$ at $\left.17.3 \mathrm{ppm}\right)$ was employed as reference for chemical shifts. The acquisitions were carried out using $90^{\circ}$ pulses for ${ }^{1} \mathrm{H}$ of $4.5 \mu \mathrm{s}$, an acquisition time of $30 \mathrm{~ms}$, a recycle delay of $2 \mathrm{~s}$, a contact time of $2 \mathrm{~ms}$ and sweep width of $50 \mathrm{kHz}$.

Elemental analysis $(\mathrm{C}$ and $\mathrm{H})$ were run using a $2400 \mathrm{CHN}$ Perkin Elmer Elemental Analyzer. Sulfur, arsenic and metals were determined by energy dispersive X-ray fluorescence (Shimadzu XRF $800 \mathrm{HS})$. Calibration curves $\left(0.1-1000 \mathrm{mg} \mathrm{kg}^{-1}\right)$ of the elements found were employed for their quantitative analyses. Crystalline phases in oxidized samples were identified by X-ray powder diffraction (Shimadzu XRD 6000) by continuous scanning method at $20 \mathrm{~mA}$ and $40 \mathrm{kV}$, using Co $\mathrm{K} \alpha$ as radiation source. Specific surface $\left(\mathrm{S}_{\mathrm{BET}}\right)$ area and average pore volume are routinely of fresh, coked and oxidized samples were determined by $\mathrm{N}_{2}$ physisorption at $77 \mathrm{~K}\left(-196{ }^{\circ} \mathrm{C}\right)$ using a Quantachrome Nova 1200e instrument. Prior to adsorption, samples (in round-bottomed glass tubes) were pretreated in vacuum $\left(10^{-5}\right.$ torr $)$ at $250{ }^{\circ} \mathrm{C}$ for $3 \mathrm{~h}$. Leached elements were determined by atomic absorption spectrometry (Perkin Elmer AAS 3300). $\mathrm{pH}$ measurements of aqueous solutions were conducted by using a combination of a glass electrode and a $\mathrm{Ag} / \mathrm{AgCl}$ reference electrode (Orion 2AI3-JG). All analyses were run in triplicate, and errors were always below $5 \%$.

\section{RESULTS AND DISCUSSION}

\section{Chemical characterization of the spent catalysts}

The amount and variety of foreign elements (Table 2) deposited on the catalyst particularly increased in the last two NiMo generation catalysts (2003-2008 and 2008-2011). These samples were directly affected by the quality of the crude diesel and their corresponding feedstocks (Table 1). ${ }^{15,17}$ This effect seemed to be enhanced by the severity of HDS conditions, since the fourth generation only worked under ultra-deep HDS conditions, ${ }^{2,9,17}$ whereas the third one worked only in its last year in service. The presence of silicon can be explained by the use of silicone for foam control in offshore petroleum production, ${ }^{7}$ whereas some iron came from corrosion/abrasion of the hydrotreater. ${ }^{12,26}$ Vanadium, arsenic and calcium have already been reported in spent catalysts from hydroprocessing of heavy feedstocks under severe conditions. ${ }^{19,21,23,34}$

The amounts of molybdenum and nickel are the highest in the last two NiMo generation catalysts. This is a way to increase the activity of the current catalyst technology for ultra-deep HDS..$^{32-37}$ This also explains the higher amount of sulfur in these samples since the HDS catalysts work in sulfide form during their time on stream. The higher amount of support additives ( $\mathrm{P}, \mathrm{Si}$ ) is another strategy to improve HDS activity via inclusion of acidic functionality. ${ }^{31,32,36,37}$

Carbon content decreased in the last NiMo generation catalysts despite the more severe HDS conditions (Table 1). This point will be discussed further.

\section{$\mathrm{H} / \mathrm{C}$ atomic ratio}

The H/C atomic ratio (Table 3) decreased, especially for the last NiMo generation catalyst. This result indicates that coke became more aromatic (lower hydrogen content), ${ }^{12,14,22,26}$ probably due to the combined effect of the feedstock and ultra-deep HDS conditions. ${ }^{9}$

$\mathrm{H} / \mathrm{C}$ atomic ratios below 1.3 are typical of the so-called "hard" coke. ${ }^{19,25}$ The "soft" coke is formed at the initial stage of hydroprocessing; it is the main cause of the loss of micropores and consequently the surface area and the porosity of the catalyst. The "hard" coke, which is formed in later stages takes up the remaining porosity. ${ }^{9}, 19,24,25$ The soft coke has a higher hydrogen to carbon ratio

Table 2. Chemical analysis (wt.\%, dry basis) of the spent and fresh $\mathrm{NiMo} / \mathrm{Al}_{2} \mathrm{O}_{3}$ catalysts

\begin{tabular}{|c|c|c|c|c|c|c|c|c|}
\hline \multirow{2}{*}{ Generation } & \multicolumn{2}{|c|}{$\begin{array}{c}\text { I } \\
1979-1986 \\
\end{array}$} & \multicolumn{2}{|c|}{$\begin{array}{c}\text { II } \\
1993-1998 \\
\end{array}$} & \multicolumn{2}{|c|}{$\begin{array}{c}\text { III } \\
2003-2008 \\
\end{array}$} & \multicolumn{2}{|c|}{$\begin{array}{c}\text { IV } \\
\text { 2008-2011 }\end{array}$} \\
\hline & fresh & spent & fresh & spent & fresh & spent & fresh & spent \\
\hline $\mathrm{Al}_{2} \mathrm{O}_{3}$ & 82.9 & 64.7 & 77.4 & 58.5 & 71.5 & 51.0 & 71.1 & 48.9 \\
\hline $\mathrm{MoO}_{3}$ & 13.3 & 10.1 & 14.2 & 10.6 & 20.9 & 15.0 & 20.2 & 14.6 \\
\hline $\mathrm{SO}_{3}$ & absent & 8.8 & absent & 10.6 & absent & 14.0 & absent & 15.1 \\
\hline $\mathrm{SiO}_{2}$ & $<0.1$ & 0.3 & 2.0 & 2.0 & 1.5 & 3.0 & 1.5 & 4.0 \\
\hline $\mathrm{NiO}$ & 2.5 & 2.0 & 2.6 & 2.1 & 2.9 & 2.2 & 3.4 & 2.9 \\
\hline $\mathrm{P}_{2} \mathrm{O}_{5}$ & 1.1 & 0.7 & 3.7 & 3.0 & 3.2 & 2.3 & 3.7 & 2.6 \\
\hline $\mathrm{Fe}_{2} \mathrm{O}_{3}$ & absent & 0.3 & absent & 0.7 & absent & 1.9 & absent & 2.1 \\
\hline $\mathrm{CaO}$ & \multicolumn{2}{|c|}{ absent } & \multicolumn{2}{|c|}{ absent } & absent & 0.3 & 0.1 & 0.4 \\
\hline $\mathrm{As}_{2} \mathrm{O}_{3}$ & \multicolumn{2}{|c|}{ absent } & \multicolumn{2}{|c|}{ absent } & absent & 0.1 & absent & 0.2 \\
\hline $\mathrm{V}_{2} \mathrm{O}_{5}$ & \multicolumn{2}{|c|}{ absent } & \multicolumn{2}{|c|}{ absent } & \multicolumn{2}{|c|}{ absent } & absent & 0.3 \\
\hline $\mathrm{CuO}$ & \multicolumn{2}{|c|}{ absent } & \multicolumn{2}{|c|}{ absent } & \multicolumn{2}{|c|}{ absent } & absent & $4 \times 10^{-2}$ \\
\hline $\mathrm{MnO}$ & \multicolumn{2}{|c|}{ absent } & \multicolumn{2}{|c|}{ absent } & \multicolumn{2}{|c|}{ absent } & absent & $3 \times 10^{-2}$ \\
\hline $\mathrm{C}$ & absent & 13.0 & absent & 12.5 & absent & 10.2 & absent & 8.8 \\
\hline
\end{tabular}


than the hard one. ${ }^{19,25}$ As the time on stream increased the structure of the carbonaceous deposits shifted towards increasing aromaticity, forming a graphite-like structure. ${ }^{4,12,14,26}$

Table 3. $\mathrm{H} / \mathrm{C}$ atomic ratio of coke deposited on spent $\mathrm{NiMo} / \mathrm{Al}_{2} \mathrm{O}_{3}$ catalysts

\begin{tabular}{cc}
\hline Spent $\mathrm{NiMo} \mathrm{Al}_{2} \mathrm{O}_{3}$ generation catalyst & $\mathrm{H} / \mathrm{C}$ atomic ratio \\
\hline I (1979-1986) & 1.61 \\
II (1993-1998) & 1.45 \\
III (2003-2008) & 1.43 \\
IV (2008-2011) & 1.17 \\
\hline
\end{tabular}

\section{${ }^{13}$ C CP-MAS NMR data}

All spectra (Figures 1 to 4 ) present peaks falling in the $\mathrm{C}_{s p}{ }^{3}$ and $\mathrm{C}_{s p}{ }^{2}$ zones $\left(0-60\right.$ and $120-160 \mathrm{ppm}$, respectively). ${ }^{37}$ The shape of these peaks indicates a great variety of saturated and unsaturated carbons, thus reflecting the complex structure of coke deposited on the catalysts. The integral areas of $\mathrm{C}_{s p}{ }^{3}$ and $\mathrm{C}_{s p}{ }^{2}$ peaks give an approximate estimate of the molar composition of the coke deposited on the catalyst, although the extent of transfer of magnetization from the proton system to the carbons depends upon the nature of coke compounds. ${ }^{22,37}$ Nevertheless, the peak of the $\mathrm{C}_{\mathrm{sp}}{ }^{2}$ region became more important along the NiMo generation catalysts. Over $50 \%$ of the carbons of the coke deposited on the last generation are aromatic (Table 4). This correlates to the experimental conditions and the quality of the crude diesel (therefore, the original feedstock) processed in each case (Table 1). ${ }^{9,12,14,19,38}$ This result also agrees very well with $\mathrm{H} / \mathrm{C}$ atomic ratio data (Table 3 ).
The profile of coke deposited on a catalyst surface is not only dependent on its amount (wt.\%), but also on its chemical nature. Although the amount deposited is lower (Table 2), the coke of the last NiMo generation catalyst is more refractory due to its higher aromatic character. ${ }^{19,25,28}$

\section{Textural properties}

The last two NiMo generation fresh catalysts present a higher surface area and a larger pore volume than the first ones (Table 5). This is a strategy to increase catalyst activity under ultra-deep HDS conditions. . $^{2,3,12,17}$

Both surface area and pore volume of spent catalysts markedly decreased when ultra-deep HDS conditions were employed. Although the amount of coke deposited was lower (Table 2), the amount of foreign elements ( $\mathrm{V}, \mathrm{As}, \mathrm{Ca}, \mathrm{Fe}, \mathrm{Cu}, \mathrm{Mn}$ ) in these samples increased (Table 2). ${ }^{9,11,23,24}$ Besides coke and elements deposition, textural properties are very sensitive to the more severe HDS conditions (that lead to the shortening of the lifetime of the catalysts) $)^{30-33}$ and the quality of crude diesel processed. ${ }^{12,17}$

\section{Characterization of the oxidized catalysts}

\section{Loss of volatiles}

Data for the first two NiMo generation catalysts (Table 6) agree with literature data for spent catalysts under conventional HDS conditions. ${ }^{28,29,38}$ However, loss of volatiles was lower for the two last generations. This is partially explained by the lower amount of coke in these samples (Table 2). However, the amount of remaining sulfur was higher (Table 6). A possible explanation is the oxidation of sulfur to sulfate species, thus reducing the amount of the element

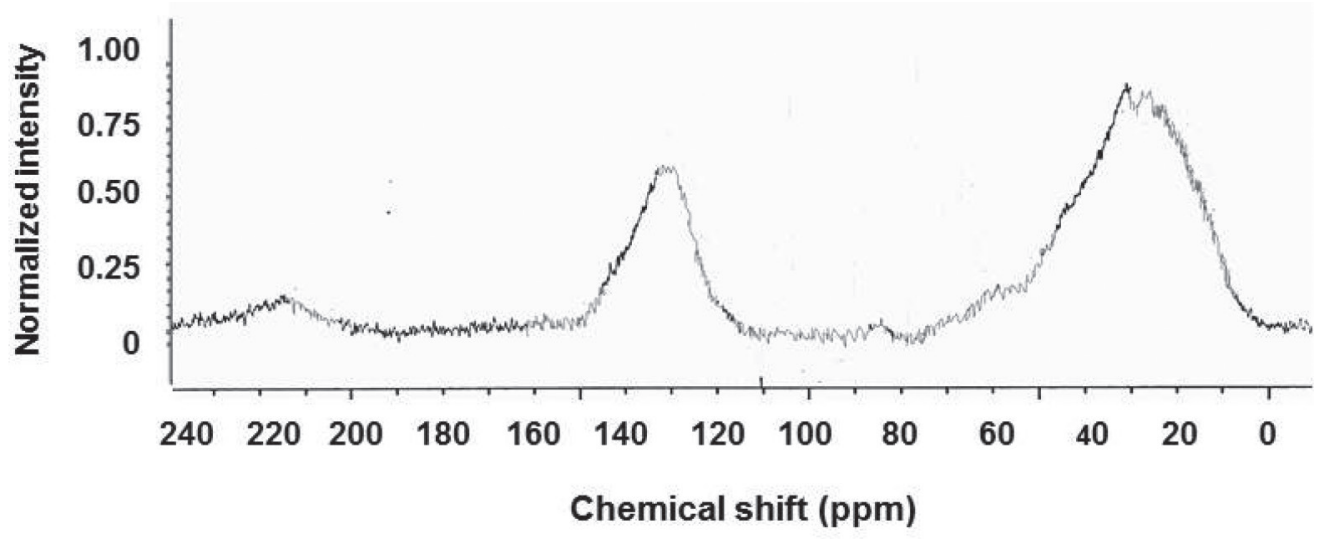

Figure 1. ${ }^{13} \mathrm{C} C \mathrm{CP}-\mathrm{MAS} \mathrm{NMR}$ spectrum of the spent $\mathrm{NiMo} / \mathrm{Al}_{2} \mathrm{O}_{3}$ catalyst (1979-1986)

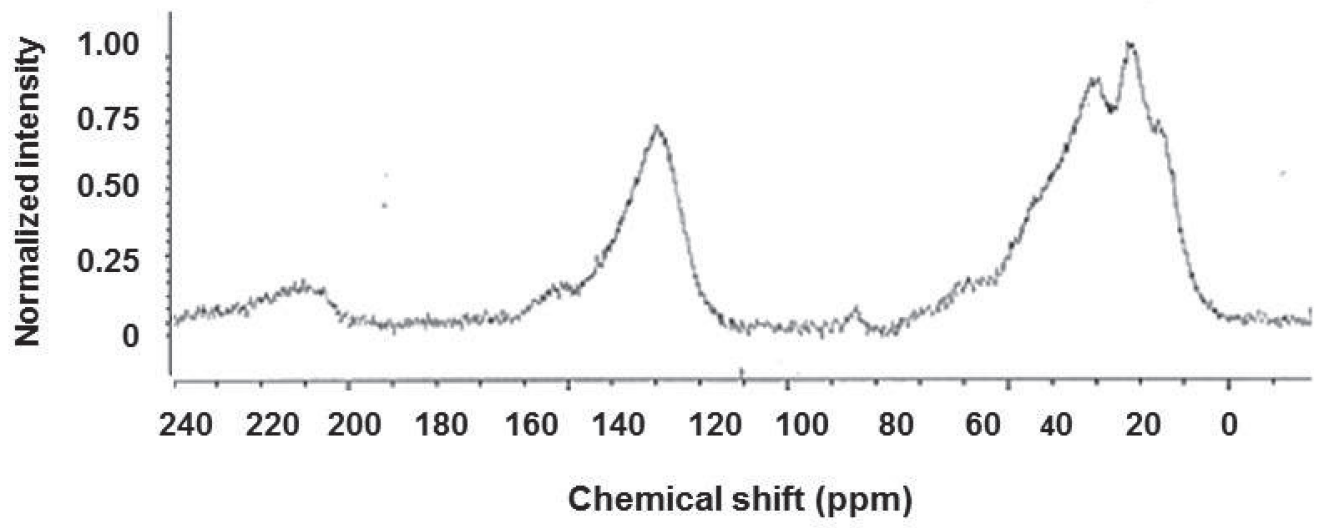

Figure $2 .{ }^{13} \mathrm{C} C P$-MAS NMR spectrum of the spent $\mathrm{NiMo}_{\mathrm{A}} \mathrm{Al}_{2} \mathrm{O}_{3}$ catalyst (1993-1998) 


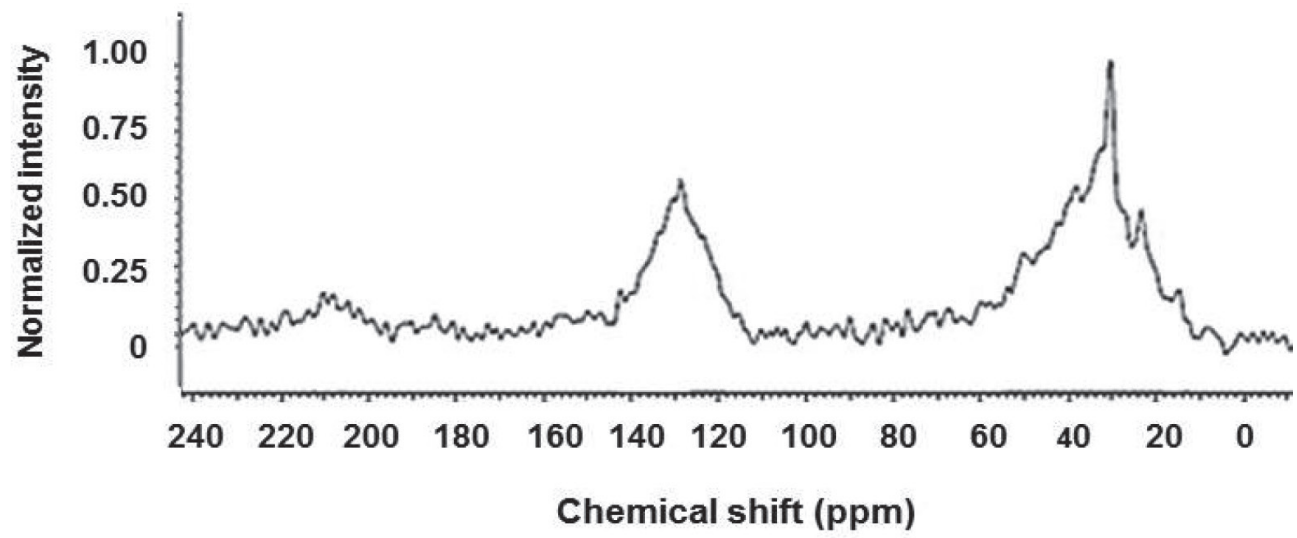

Figure 3. ${ }^{13} \mathrm{C} \mathrm{CP}$-MAS NMR spectrum of the spent $\mathrm{NiMo} / \mathrm{Al}_{2} \mathrm{O}_{3}$ catalyst (2003-2008)

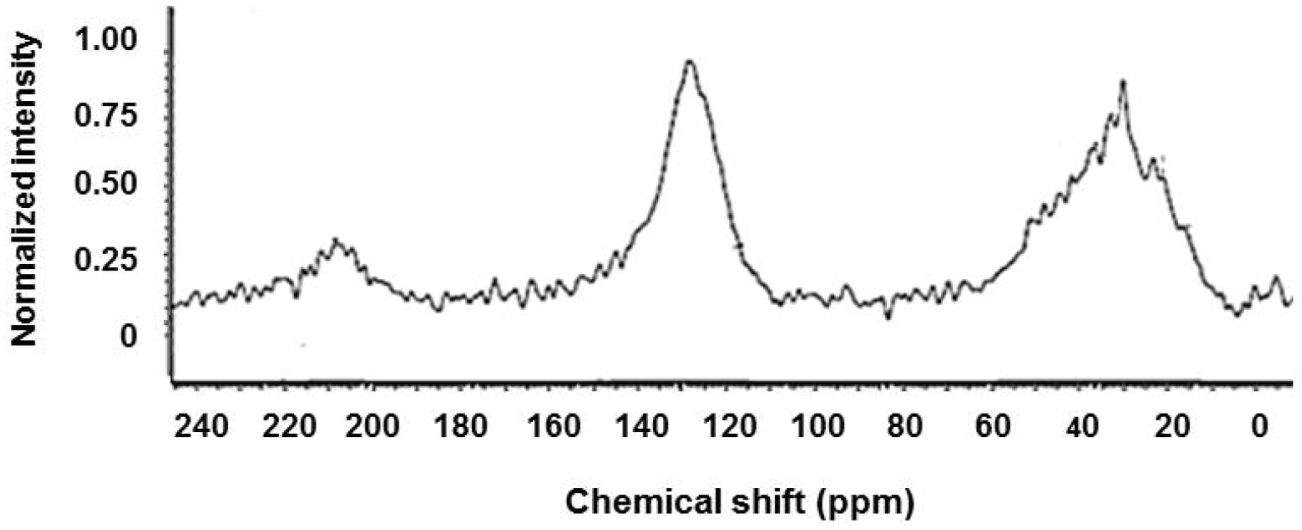

Figure 4. ${ }^{13} \mathrm{C} C P$-MAS NMR spectrum of the spent $\mathrm{NiMo} / \mathrm{Al}_{2} \mathrm{O}_{3}$ catalyst (2008-2011)

Table 4. Aromatic and aliphatic coke content (mol\%) derived from peak areas of ${ }^{13} \mathrm{C}$ CP-MAS NMR spectra

\begin{tabular}{ccc}
\hline $\begin{array}{c}\text { Spent } \mathrm{NiMo} / \mathrm{Al}_{2} \mathrm{O}_{3} \\
\text { generation catalyst }\end{array}$ & $\begin{array}{c}\mathrm{C}_{\mathrm{sp}}{ }^{3} \text { (aliphatic) } \\
(20-60 \mathrm{ppm})\end{array}$ & $\begin{array}{c}\mathrm{C}_{\mathrm{sp}}{ }^{2} \text { (aromatic) } \\
(120-160 \mathrm{ppm})\end{array}$ \\
\hline I (1979-1986) & 78 & 22 \\
II (1993-1998) & 71 & 29 \\
III (2003-2008) & 65 & 35 \\
IV (2008-2011) & 46 & 54 \\
\hline
\end{tabular}

Table 5. Textural properties of fresh and spent $\mathrm{NiMo} / \mathrm{Al}_{2} \mathrm{O}_{3}$ catalysts

\begin{tabular}{lcccc}
\hline \multirow{2}{*}{$\begin{array}{l}\mathrm{NiMo} / \mathrm{Al}_{2} \mathrm{O}_{3} \\
\text { generation catalyst }\end{array}$} & \multicolumn{2}{c}{$\mathrm{S}_{\mathrm{BET}}\left(\mathrm{m}^{2} \mathrm{~g}^{-1}\right)$} & \multicolumn{2}{c}{$\mathrm{V}\left(\mathrm{cm}^{3} \mathrm{~g}^{-1}\right)$} \\
\cline { 2 - 5 } & fresh & spent & fresh & spent \\
\hline I (1979-1986) & 160 & 93 & 0.40 & 0.21 \\
II (1993-1998) & 160 & 88 & 0.45 & 0.25 \\
III (2003-2008) & 225 & 113 & 0.51 & 0.22 \\
IV (2008-2011) & 240 & 76 & 0.50 & 0.15 \\
\hline
\end{tabular}

eliminated as $\mathrm{SO}_{2(\mathrm{~g})}$. Metals such as vanadium can catalyze this conversion..$^{39,40}$ To assess this hypothesis $100 \mathrm{mg}$ of an oxidized sample were placed in a $25 \mathrm{~mL}$ beaker containing $10 \mathrm{~mL}$ of water at $90{ }^{\circ} \mathrm{C}$ under stirring $(200 \mathrm{rpm})$. After $10 \mathrm{~min}$ the solid was filtered and some drops of $0.2 \mathrm{~mol} \mathrm{~L}^{-1} \mathrm{Ba}\left(\mathrm{NO}_{3}\right)_{2}$ were added to the filtrate. A white precipitate $\left(\mathrm{BaSO}_{4}\right)$, insoluble in concentrated $\mathrm{HCl},{ }^{41,42}$ was formed, thus confirming the presence of sulfate species in the samples under study.

The oxidation of deposited elements in the reduced state (As(III), $\mathrm{V}(\mathrm{III}), \mathrm{Fe}(\mathrm{II})),{ }^{38,39,43}$ as well as $\mathrm{Mo}(\mathrm{IV}),^{2,34,35,38}$ to higher oxidation states during coke removal (As(V), V(V), Fe(III) and Mo(VI)) also explains the lower mass loss for the most recent NiMo generation catalysts.

During oxidation, the temperature of the catalyst bed suddenly rose from $\sim 460$ to $900{ }^{\circ} \mathrm{C}$ in about $10 \mathrm{~min}$ for the two most recent NiMo generation catalysts, despite the low heating rate $\left(3{ }^{\circ} \mathrm{C} \mathrm{min}{ }^{-1}\right)$. This phenomenon was not observed for the two oldest generation catalysts. These samples only ignited when high rates were employed $\left.\left(10^{\circ} \mathrm{C} \mathrm{min}^{-1}\right)\right)^{7,28,43}$ It seems to have a relationship between the aromaticity of coke and the sample ignition: the greater the aromatic character, the highest the temperature of the catalytic bed after ignition. As coke becomes more aromatic, the risk of ignition increases during heating of the coked sample. ${ }^{12,14,24,26,28,29}$ The "hard" coke ignites at higher temperatures than the "soft" one. . $^{12,14,24,26,29}$

Table 6. Average mass and sulfur losses of samples oxidized at $500^{\circ} \mathrm{C}$ for $3 \mathrm{~h}$

\begin{tabular}{ccc}
\hline $\begin{array}{c}\text { Spent } \mathrm{NiMo} / \mathrm{Al}_{2} \mathrm{O}_{3} \\
\text { generation catalyst }\end{array}$ & $\begin{array}{c}\text { Mass loss } \\
\text { (wt.\%) }\end{array}$ & $\begin{array}{c}\text { Sulfur loss } \\
\text { (wt.\%) }\end{array}$ \\
\hline I (1979-1986) & 27 & 80 \\
II (1993-1998) & 25 & 74 \\
III (2003-2008) & 24 & 64 \\
IV (2008-2011) & 21 & 55 \\
\hline
\end{tabular}

The aspect of the oxidized samples is quite different from the deactivated ones. After coke removal the color of the oxidized catalyst should be green due to the presence of nickel in its active phase, but samples from the third and fourth generations are reddish in color (Figure 5) due to the presence of iron deposited over their surface in considerable amounts (Table 2). 


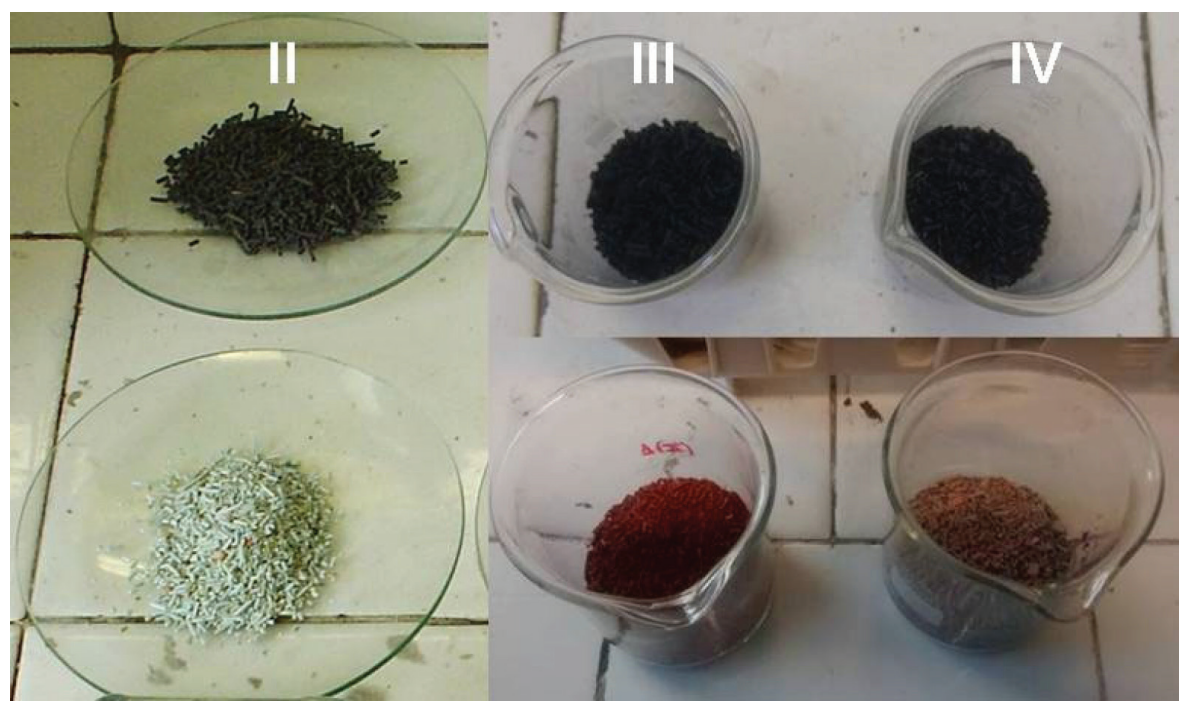

Figure 5. Aspect of the catalysts from the second (left) to the fourth (right) NiMo generation catalysts before (above) and after (below) oxidation at $500{ }^{\circ} \mathrm{C}$ for $5 \mathrm{~h}$. The reddish color is due to iron deposited over the surface

\section{XRD data}

Figure 6 presents the diffractograms of the oxidized catalysts. All samples exhibit low crystallinity. Only ill-defined peaks corresponding to $\gamma-\mathrm{Al}_{2} \mathrm{O}_{3}$ appeared in the diffractograms of the last two spent NiMo generation catalysts. Despite the increase of the aromatic character of the coke in these samples, it appears that coke ignition did not lead to significant crystallization of inorganic components of the catalysts..$^{29}$ Although our XRD data do not show crystalline phases, other work state the formation of spinel-like compounds $\left(\mathrm{NiAl}_{2} \mathrm{O}_{4}\right)$,
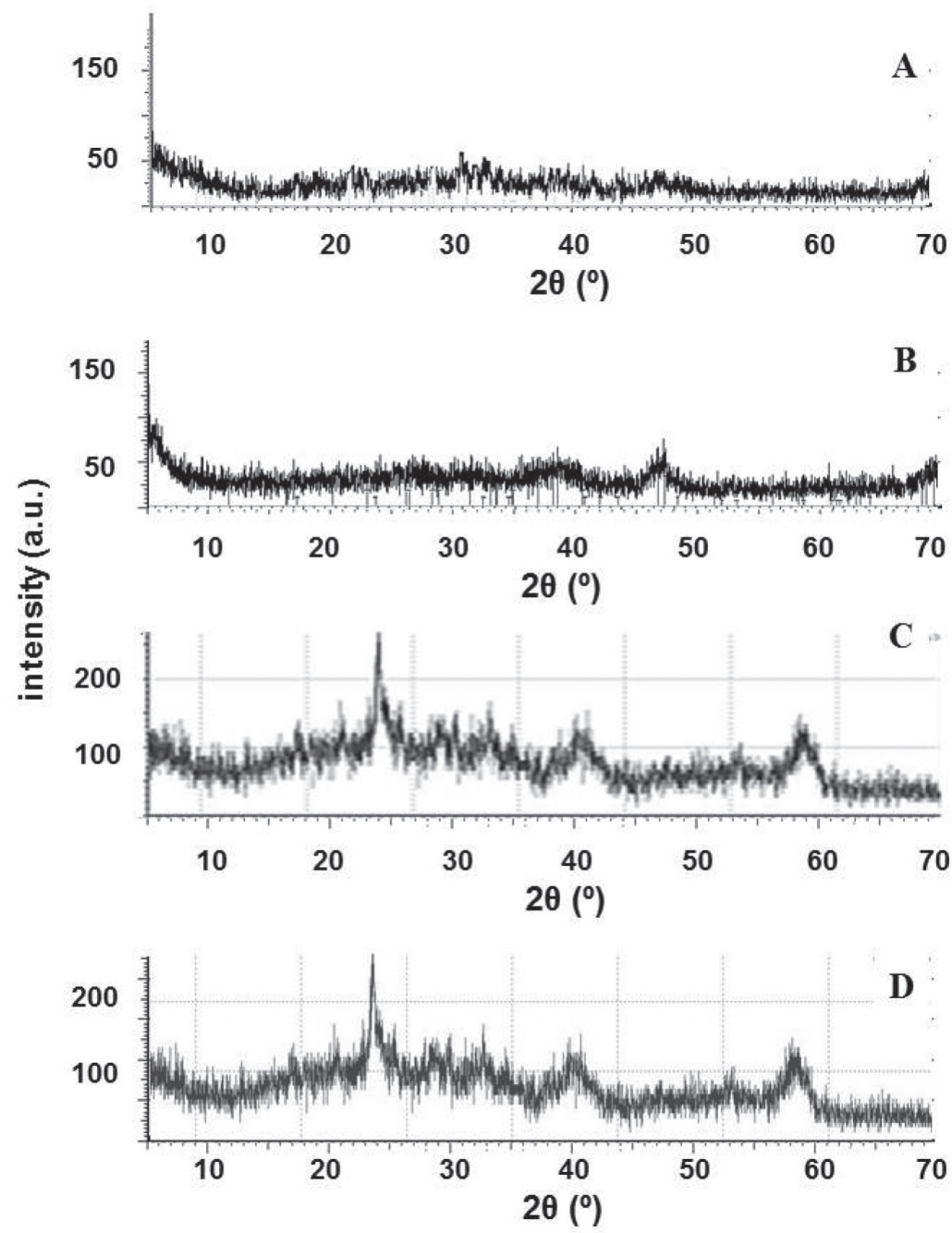

Figure 6. X-ray diffractograms of the oxidized NiMo/Al $\mathrm{O}_{3}$ catalyst: 1979-1986 (A); 1993-1998 (B); 2003-2008 (C); $2008-2011$ (D) 
molybdates $\left(\mathrm{NiMoO}_{4}\right)$, phosphates $\left(\mathrm{Ni}_{3}\left(\mathrm{PO}_{4}\right)_{2}\right)$ and metasilicates $\left(\mathrm{NiSiO}_{3}\right)$ when spent hydroprocessing catalysts are subjected to high temperatures (above $800{ }^{\circ} \mathrm{C}$ )..$^{44,45}$

\section{Acidic leaching}

The amount of insoluble matter after leaching with sulfuric acid sharply increased from the second $(\sim 1.3 \mathrm{wt} . \%)$ to the fourth NiMo catalyst generation ( 73 wt.\%) (Figure 7). It seems to have a relationship between the amount of insoluble matter in sulfuric acid and the aromaticity of coke: the greater the aromaticity the greater the amount of insoluble matter. Data on Table 7 corroborates data presented in Figure 7. Leaching of elements markedly decreased from the first two generations to the last one. Even those deposited on the catalyst surface (Fe, As, V) were poorly leached from this sample.

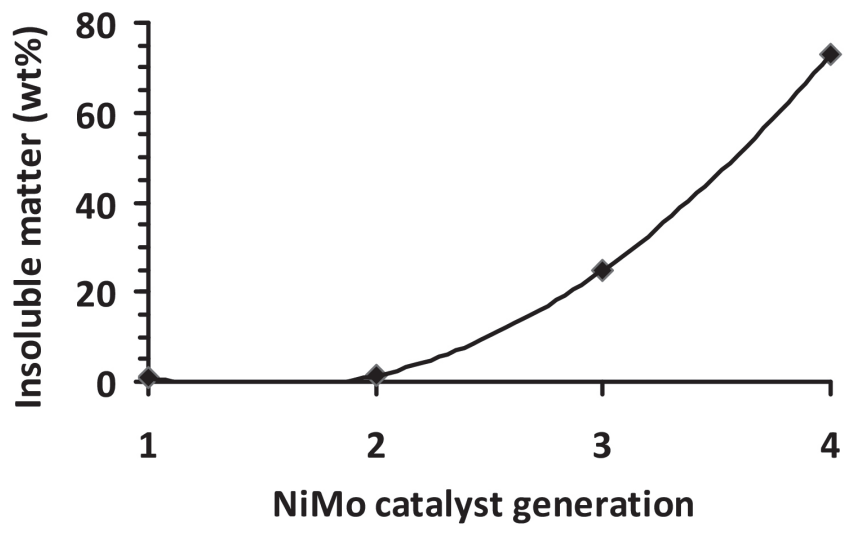

Figure 7. Amount (wt.\%) of insoluble matter after leaching of pre-oxidized catalysts with $9 \mathrm{~mol} \mathrm{~L}^{-1} \mathrm{H}_{2} \mathrm{SO}_{4}\left(90^{\circ} \mathrm{C}, 200 \mathrm{rpm}, 70-90 \mathrm{~min}\right)$

Table 7. Amount of leached elements (wt.\%) in $9 \mathrm{~mol} \mathrm{~L}^{-1} \mathrm{H}_{2} \mathrm{SO}_{4}\left(90{ }^{\circ} \mathrm{C}\right.$, $200 \mathrm{rpm}, 70-90 \mathrm{~min})$ after previous oxidation of catalysts $\left(500^{\circ} \mathrm{C}, 5 \mathrm{~h}\right.$, $\left.3{ }^{\circ} \mathrm{C} \mathrm{min}^{-1}\right)$

\begin{tabular}{ccccc}
\hline \multirow{2}{*}{ Element } & \multicolumn{4}{c}{ Catalyst generation } \\
\cline { 2 - 5 } & I & II & III & IV \\
\hline $\mathrm{Ni}$ & $>99.5$ & 99.5 & 86.0 & 14.5 \\
$\mathrm{Mo}$ & $>99.5$ & 99.0 & 72.5 & 11.0 \\
$\mathrm{Al}$ & 99.5 & 99.5 & 55.8 & 20.0 \\
$\mathrm{P}$ & 86.4 & 75.5 & 37.5 & 15.5 \\
$\mathrm{~S}$ & 99.0 & 99.0 & 72.0 & 45.0 \\
$\mathrm{Fe}$ & $>99.5$ & 99.5 & 80.0 & 40.0 \\
$\mathrm{As}$ & absent & absent & $>99.0$ & 20.0 \\
$\mathrm{~V}$ & absent & absent & absent & 15.0 \\
\hline
\end{tabular}

Coke removal is the most critical parameter to ensure an efficient leaching. ${ }^{24,26,29,44,46}$ The catalyst must be pre-oxidized at low heating rates in order to minimize losses of valuable components due to formation of insoluble compounds in the leachant upon coke ignition. ${ }^{7}$ The low heating rate employed $\left(3{ }^{\circ} \mathrm{C} \mathrm{min}^{-1}\right)$ was adequate to pre-oxidize spent NiMo catalysts from the first and second generations: ${ }^{7,28}$ no coke ignition was observed. However, this rate was not able to avoid ignition in samples subjected to ultra-deep HDS. Therefore, coke removal from such samples should be redrawn: very low heating rates, the use of diluted $\mathrm{O}_{2}$ in an inert gas (instead of air) or even grinding of the spent catalyst before oxidation are alternatives to be searched. These points are under investigation in many research centers. ${ }^{45-47}$
If a spent $\mathrm{NiMo}$ catalyst contains only $\mathrm{Al}, \mathrm{Si}$, and $\mathrm{Fe}$, it can be disposed of in industrial dumps without any special precautions or can be used as alternative raw material (co-processing) in construction materials. ${ }^{44}$ However, if $\mathrm{Ni}$, As and $\mathrm{V}$ accumulated during their use, they must be encapsulated before disposal in order to avoid release of such elements into the environment. ${ }^{45}$ Regeneration, rejuvenation and reuse in less severe hydroprocessing units by cascading before final disposal are not feasible because these elements poison irreversibly the active sites. ${ }^{23,46,47}$ Metals recovery from spent catalysts is the best alternative to avoid dumping such wastes but new methodologies should developed to overcome challenges such as removal of a highly aromatic coke and leaching of elements deposited on their surface.

\section{CONCLUSIONS}

As the feedstock was heavier and dirtier and the HDS conditions were more severe in the same hydrotreater, the textural properties of spent NiMo catalysts were drastically affected, the amount and variety of foreign elements deposited on their surface increased, coke tended to be more aromatic and was susceptible to ignition even under low heating rates. Mass loss was lower for the most recent NiMo generation catalysts due to a combination of three factors: the lower carbon content, the presence of high amounts of residual sulfur and the oxidation of some foreign elements deposited on the catalyst surface.

Leaching of the oxidized catalysts by sulfuric acid under classical experimental conditions was ineffective for those subjected to ultra-deep HDS conditions. This is directly related to coke ignition. Therefore, new pretreatment protocols must be developed because metals leaching is strongly dependent on the reactivity of inorganic compounds present after coke removal.

\section{ACKNOWLEDGMENTS}

Tatiana M. Pessanha and Carolina Leão Quintanilha acknowledge Agência Nacional de Petróleo, Gás Natural e Biocombustíveis (ANP) for a fellowship. We are grateful to ANP and CNPq for financial support. We are grateful to LABRMN/IQ-UFRJ (Laboratório de Ressonância Magnética Nuclear) for ${ }^{13} \mathrm{C}$ CP-MAS NMR spectra.

\section{REFERENCES}

1. Rodríguez, E.; Félix, G.; Anchyeta, J.; Trejo, F.; Fuel 2018, 225, 118.

2. Vogelaar, B. M.; Eijsbouts, S.; Bergwerff, J. A.; Heiszwolf, J. J.; Catal. Today 2010, 154, 256.

3. Leyvaa, C.; Ancheyta, J.; Marieyb, L.; Travertb, A.; Maugé, F.; Catal. Today 2014, 220-222, 89.

4. Kohli, K.; Prajapati, R.; Maity, S. K.; Sal, M.; Sharma, B. K.; Fuel 2019, $235,437$.

5. Torres-Mancera, P.; Anchyeta, J.; Martínez, J.; Fuel 2018, 234, 326.

6. Wang, L.; Chao, L.; Qu, W.; Xu, S.; Zhang, L.; Peng, J.; Ye, X.; Ultrason. Sonochem. 2018, 49, 24.

7. Valverde Jr., I. M.; Paulino, J. F.; Afonso, J. C.; J. Hazard. Mater. 2008, $160,310$.

8. Imam, D. M.; El-Nadi, Y. A.; Hydrometallurgy 2018, 180, 172.

9. Rana, M. S.; Ancheyta, J.; Sahoo, S. K.; Rayo, P.; Catal. Today 2014, 220-222, 97.

10. Yang, Y.; Shengming, X.; Li, Z.; Wang, J.; Zhao, Z.; Xu, Z.; J. Hazard. Mater. 2016, 318, 723.

11. Koh, J. H.; Lee, J. J.; Kim, H.; Cho, A.; Moon, S. H.; Appl. Catal. B: Environ. 2009, 86176.

12. Guichard, B.; Auberger, M. R.; Devers, E.; Legens, C.; Raybaud, P.; Catal. Today 2008, 130, 97. 
13. Marchala, C.; Uzioa, D.; Merdrignaca, I.; Barreb, L.; Geantet, C.; Appl. Catal. A: Gen. 2012, 411-412, 35.

14. Guichard, B.; Roy-Auberger, M.; Devers, E.; Rebours, B.; Quoineaud, A. A.; Digne, M.; Appl. Catal. A: Gen. 2009, 367, 1.

15. Ramirez, S.; Leyva, C.; Ancheyta, J.; Centeno, G.; Fuel 2009, 88, 2311.

16. Gawel, I.; Bociarska, D.; Biskupski, P.; Appl. Catal. A: Gen. 2005, 295 , 89.

17. Marafi, M.; Al-Sheeha, H.; Al-Omani, S.; Al-Barood, A.; Fuel Process. Technol. 2009, 90, 264.

18. Callejas, M. A.; Martınez, M. T.; Blasco, T.; Sastre, E.; Appl. Catal. A: Gen. 2001, 218, 181.

19. Maity, S. K.; Blanco, E.; Ancheyta, J.; Alonso, F.; Fukuyama, H.; Fuel 2012, 100, 17.

20. Torres-Mancera, P.; Rayo, P.; Ancheyta, J.; Marroquín, G.; Centeno, G.; Alonso, F.; Catal. Today 2014, 220-222, 153.

21. Yue, Y.; Tiantian, C.; Yong, X.; GuoYong, H.; Wenqiang, W.; Qi, L.; Shengming, X.; Waste Manage. 2018, 78, 595.

22. Wood, J.; Gladden, L. F.; Appl. Catal. A: Gen. 2003, 249, 241.

23. Maity, S. K.; Ancheyta, J.; Alonso, F.; Rayo, P.; Fuel Process. Technol. 2013, 106, 453.

24. Afonso, J. C.; Aranda, D. A. G.; Schmal, M.; Fréty, R.; Fuel Process. Technol. 1995, 42, 3 .

25. Afonso, J. C.; Schmal, M.; Fréty, R.; Fuel Process. Technol. 1994, 41, 13.

26. Guichard, B.; Roy-Auberger, M.; Devers, E.; Pichon, C.; Legens, C.; Appl. Catal. A: Gen. 2009, 367, 9.

27. Vogelaar, B. M.; van Langeveld, A. D.; Eijsbouts, S.; Moulijn, J. A.; Fuel 2007, 86, 1122.

28. Afonso, J. C.; Silva, G. C.; Aguiar, R. M.; Stud. Surf. Sci. Catal. 2001, 139,165 .

29. Pereira, A. L. S.; Silva, C. N.; Mantovano, J. L.; Afonso, J. C.; Quim. Nova 2011, 34, 145.
30. Kim, T.; Ali, S. A.; Alhooshani, K.; Park, J. I.; Al-Yami, M.; Yoon, S. H.; Mochida, I.; J. Ind. Eng. Chem. 2013, 19, 1577.

31. Song, C.; Turaga, U. T.; Ma, X.; Encyclopedia of Chemical Processing, Taylor \& Francis: New York, 2006, p. 651-661.

32. Yoshimura, Y.; Toba, M.; Farag, H.; Sakanishi, K.; Catal. Surv. Asia 2004, 8,47 .

33. Pawelec, B.; Navarro, R. M.; Martin, J. M. C.; Fierro, J. L. G.; Catal. Sci. Technol. 2011, 1, 23.

34. Stanislaus, A.; Marafi, A.; Rana, M. S.; Catal. Today 2010, 153, 1.

35. González-Cortés, S. L.; Rugmini, S.; Xiao, T.; Green, M. L. H.; Rodulfo-Baechler, S. M.; Imbert, F. E.; Appl. Catal. A: Gen. 2014, 475, 270.

36. Trejo, F.; Rana, M. S.; Ancheyta, J.; Chávez, S.; Fuel 2014, 138, 104.

37. Moreau, C.; Joffre, J.; Saenz, C.; Afonso, J. C.; Portefaix, J. L.; J. Mol. Catal. A: Chem. 2000, 161, 141.

38. Topsoe, H.; Clausen, B. S.; Massoth, F. E.; Hydrotreating Catalysts Science and Technology, Springer-Verlag: Berlin, 1996.

39. Wachs, I. E.; Dalton Trans. 2013, 42, 11762.

40. Hubaut, R.; Appl. Catal. A: Gen. 2007, 322, 121.

41. Feigl, F.; Spot Tests in Inorganic Analysis, Elsevier: Amsterdam, 1958, chap. 3 .

42. Lurie, J.; Handbook of Analytical Chemistry, $3^{\text {rd }}$ ed., Mir: Moscow, 1978, chap. 3, 6 and 10.

43. Wu, H.; Duan, A.; Zhao, Z.; Qi, D.; Li, J.; Liu, B.; Jiang, G.; Liu, J.; Wei, Y.; Zhang, X.; Fuel 2014, 130, 203.

44. Rana, M. S.; Ancheyta, J.; Sahoo, S. K.; Rayo, P.; Catal. Today 2014, 220-222, 97.

45. Sheeha, H.; Marafi, M.; Raghavan, V.; Rana, M. S.; Ind. Eng. Chem. Res. 2013, 52, 12794.

46. Akcil, A.; Vegliò, F.; Ferella, F.; Okudan, M. D.; Tuncuk, A. Waste Manage. 2015, 45, 420.

47. Yang, S.; Adjaye, J.; McCaffrey, W. C.; Nelson, A. E.; J. Mol. Catal. A: Chem. 2010, 321, 83. 